\title{
The Water-Carrier in Graeco-Roman Egypt
}

\author{
Farag Ebeid Zaki Shehata ${ }^{1}$
}

Tourist Guidance, Faculty of Tourism and Hotels, Minia University

\begin{tabular}{ll}
\hline ARTICLE INFO & Abstract \\
\hline Keywords: & $\begin{array}{l}\text { This paper aims to highlight profession of water-carrier in the Graeco- } \\
\text { Roman period through papyri, ostracas and terracotta figurines. It }\end{array}$ \\
Water-Carrier; & $\begin{array}{l}\text { discusses the implements and animals used in carrying and } \\
\text { papyri; Terracotta; } \\
\text { Graeco-Roman }\end{array}$ \\
$\begin{array}{ll}\text { (JAansporting water. It describes examples of water carrier's figurines in } \\
\text { the Egyptian museum in Cairo and Graeco Roman Museum in }\end{array}$ \\
Vol. 17, No. 1, & $\begin{array}{l}\text { Alexandria. The results reveal that the water carrier played an } \\
\text { important role in supplying water to people and quarries; they used }\end{array}$ \\
(2019), pp. 1-15. & water skins and depended on donkeys and camels in carrying water.
\end{tabular}

\section{Introduction}

Man's need for water since ancient times prompted him to pay attention to water resources and their preservation. Therefore, water was linked to an ancient profession, as the profession of water carrier, which was prevalent in the Egyptian society since the Pharaonic era. On the walls of some ancient Egyptian tombs ${ }^{1}$, the ancient Egyptian depicted a man carrying on his shoulders a large stick with two water skins hanging from its both ends ${ }^{2}$.

This paper aims to highlight the profession of water-carrier in the Graeco-Roman Egypt through analyzing papyri, ostracas and describing terracotta figurines. The paper discusses the tasks of the water carrier and clarifies the implements and animals used in carrying and transporting water. In addition, it identifies the areas that were in dire need of water carriers' services. Examples of water carrier's figurines in the Egyptian museum in Cairo and the Graeco Roman Museum in Alexandria are described methodology.

\section{The profession of water carrier through papyri and ostracas:}

\section{Water carrier in the documents of Ptolemaic Period:}

Our knowledge about the activity of the water carrier during the Ptolemaic period is concluded from seven papyri dating back to the third century $\mathrm{BC}^{3}$. The first is a papyrus from Philadelphia ${ }^{4}$, a village in the Arsinoite nome, which is a letter dating back to $257 \mathrm{BC}$ sent by Maron $^{5}$ to Zenon (Agent of the Minister of Finance). It reads ${ }^{6}$ :

"Maron to Zenon, greeting. Please assign me, if you think fit, 21/2 more drachmas for my salary ... to provide for the cost of grinding and for buying water... But do just as you think right yourself. Many persons are occupied ... those engaged in guarding a salary of 15 drachmas and ...artabas of wheat".

In another document ${ }^{7}$ from Philadelphia dating back to the Third century BC, there is a boy called Kleon who writes a memorandum to Zenon (the agent of Apollonius). It reads:

"Memorandum from Kleon to his father Zenon ${ }^{8}$. Please send us the salary or provisions that are for both me and my mother, totaling with the oil, 17 drachmas. Wine is also ours, containing 6 large chous plus 3 small cotyles, also the contribution for the festival of Hermes and the Muses ${ }^{9}$, for everyone else has already contributed. Also give interest concerning the water, for we have been buying it for many days past".

These two documents concern us as they emphasize that both the official Maron and the boy Kleon are preoccupied with the costs of buying water. Although they did not explain the kind 
of water they are preoccupied with, however it is clear from their conversation that they mean the cost of buying drinking water or water for household use in general.

According to the previous mentioned documents, we can conclude that there was a person in charge of selling fresh water or water for household use. This profession is also emphasized in other documents. One of them is a fragment of document from the city of Krokodilopolis ${ }^{10}$ in the Arsinoite nome, dating back to $26 / 27$ February of 221 BC. It is a petition submitted to the king by a person called Eutychos. It reads ${ }^{11}$ :

"Eutychos, the water carrier to the king Ptolemy, salute, I was hurt by the sons of Apollonius. When I got up my work at Elias's house ... "They rushed towards me and poured (water on the ground)..... They assaulted me and my wife as well with hands..."

From this document we know that the water carrier in the Ptolemaic period was nicknamed: $v\left(\delta \rho \circ \phi о \rho о \varphi^{12}\right.$ from the verb $v(\delta \rho \circ \phi о \rho \varepsilon \omega$, which means carrying water. He managed to carry and sell water to the homes near the water supply.

There is a collection of papyri from Arsinoe dating back to the third century BC, which are daily accounts of the costs of buying fresh water from water carriers. They recorderd:

Half A obol for water carrier ${ }^{13}$,

half A obol for water carrier ${ }^{14}$,

half A obol for the theatre water ${ }^{15}$,

to Philemon the water carrier ${ }^{16}$.

It can be concluded from these accounts that the wage of the water carrier in exchange for carrying water to houses or theatres near the water supply was half a obol ${ }^{17}$ (less than $1 / 10 \mathrm{a}$ drachma ${ }^{18}$ ) at a time during the third century BC.

\section{Water carrier in the documents and ostracas of the Roman Period:}

Considering the documentary evidence related to the profession of water carrier during the Roman era, it can be divided into two groups. The first deals with the aspects of the activity of the water carrier in supplying water to villages and cities for various purposes ${ }^{19}$. The second deals with the role of water carrier in transporting water to quarries and military installations scattered in the eastern desert of Egypt ${ }^{20}$.

Therefore, the first collection of documentary evidence will be highlighted, including a papyrus document dating back to the period between $162 \mathrm{AD}$ and $167 \mathrm{AD}$. It is a statement of account related to the agricultural work in Tebtunis village in the Arsinoite nome, stating that the cost of using four donkeys in transferring water amounted to two obols ${ }^{21}$.

Another document ${ }^{22}$, dating back to August 16, 166 AD, stated the account of the expenses of building a wine mill in Tebtunis village, including the wages of water carriers. These were as follows: "26 of water carriers ...6 obols for water carriers"

The document also contains the cost of using the water carriers' donkeys to transport water to construction sites, namely:

"14 obols for water carrier's donkey"

"2 drachmas ${ }^{23}$ for water carriers" donkey"

"4 drachmas for two donkeys to transport water"

Therefore, it turns out that the water carriers were transporting water from long distances for use in irrigating agricultural lands and constructing various architectural structures. Given the need for such large quantities of water as well as the long distance from the water supply, it was normal for water carriers to rely on donkeys to transport water. There is no doubt that the 
cost of using donkeys was related to the amount of water transported and the distance between the water source and the destined place.

It is worth mentioning that the activity of water carriers was not the transferring water for irrigation and construction only, but also for domestic use in general. There is a document ${ }^{24}$ from Memphis dating back to the second century $\mathrm{AD}$, which referred to a water carrier called Arbikhis in the same village. There are also two other documents ${ }^{25}$ dating back to the third century, one from the village of Soknopaiou Nesos ${ }^{26}$ in the Arsinoite nome, which is an account of the daily expenses. Both included a reference to the water carrier.

In addition, the city of Hermopolis Magna ${ }^{27}$ provided us with a document dating back to the period between $317 \mathrm{AD}$ and $323 \mathrm{AD}$, which is a an account, impling that the cost of buying cold water during a trip amounted to ca. 100 drachmas. This reflects the role of water carriers in selling water to travelers on roads, people in villages and cities, for use in drinking, irrigation of agricultural land and the construction of architectural facilities away from the water supply.

As for the water resource on which the water carriers relied to bring water suitable for household use or potable water in particular, there is an ostraca ${ }^{28}$ from the city of Oxyrhynchus dating back to the fourth or fifth century AD that included the following:

"In 2 Tobi. The work of Pamun, the water carrier at the pure wet river"

It is possible that this document is an official certificate confirming that the water-carrier Pamun was practicing his profession of carrying clear water from the River nile for drinking. This means that during the period between the fourth and fifth centuriy AD, Egypt witnessed an administration specialized in issuing official certificates related to practicing the water carrier profession and the conditions necessary for practicing this profession. Perhaps this administration was concerned with obliging water carriers to bring drinking water from the best sites River nile in order to keep away from any source of pollution to maintain public health.

Now, the researcher turn to the second group of documentary evidence of the water-carrier profession which dates back to the Roman Period. These documents related to the activity of water-carriers in the quarries and military establishments deployed in the eastern desert of Egypt. It is worth pointing out that almost all the evidence is represented by the ostracas from Mount Claudianus ${ }^{29}$. This area included several quarries and were inhabited by military commanders, soldiers, civilians of skilled and unskilled workers, as well as women and children $^{30}$.

It was normal for these settlers to include workers for practicing the water carrying profession. This is witnessed by a number of ostracas ${ }^{31}$ from the Claudianus quarries, dating back to the period between 136 and $137 \mathrm{AD}^{32}$.

Fragment 1: Part (1)

"1 The 7th. Carrying water-skins, 34 men. For firewood, 6 men. Temperers, bellows-men, 8 men. In the stomoterion, 3 men. In the watch-tower, 3 men. Water-carriers in the quarry, 3 men. Workers in the quarry, 9 men. Guards of the living quarters, 3 men. In the bakery, 2 men. Platearius 1. Total 72 men".

Part (2)

"12 The 8th. Carrying water-skins, 37 men. In the quarry, 15 men. For firewood, 5 men. Temperers, bellows-men, 8 men. In the stomoterion, 3 men. In the watch-tower, 2 men. Water-carriers in the quarry, 3 men. In the bakery, 2. Guards of the living quarters, 3 men. Platearius, 1. Total, 74 men". 
Part (3)

"23 The 9th. Carrying water-skins, 32 men. In the quarry, 20 men. For firewood, 10 men Temperers, bellows-men 6 men ...

fragment 2:

"28 .. Water-carriers 10 men. In the stomoterion 10 men. In the bakery, 10 men. Platearius 1. Total 20 men".

The previous document provides information on the distribution of works to the workers of Claudianus quarries. It stated the prominent tasks related to water carriers, which come first of all daily works as evidenced by the text. It can be understood that in the seventh day it was decided to assign 34 men to move the waterskins and 3 men to carry water to the quarry; on the eighth day, 37 men for transporting waterskins and three men for carrying water to the quarry; on the ninth day, 32 men for transporting waterskins and 10 to carry water to the quarry. This meant that water carriers were working daily at Claudianus quarries, it is clear that they were divided into two groups: the first group known as $\alpha 0 \kappa o v \alpha \& \rho 101 \lambda \alpha \tau$ o $\mu 1 \& \alpha$ was carrying water to the quarry. The second group, called $\alpha 0 \sigma \kappa o \phi о \rho ı \& \alpha$ was responsible for bringing potable water from the reservoirs to the workers. This reflects the large number of water carriers in the quarries of Claudianus.

This emphasizes the need for Claudianus quarries in particular and the Eastern desert in general for the services of water carriers. Therefore, the available documentary evidence included information on:

1- The means upon which the water carriers relied to carry water and the methods of keeping.

2 - The places where the water carriers go to bring fresh water.

3- The fresh water tanks in Claudianus quarries.

\section{Means of carrying and supplying water:}

An ostraca ${ }^{33}$ from Claudianus quarries dated back to $107 \mathrm{AD}$ mentioned that there was a woman called Grata telling the following to someone called Successus ${ }^{34}$ :

\section{A Letter from Grata to Successus}

"Grata to Successus, her brother, many greetings. I notified Artimas about the 140 waterskins and he answered that he had neither received them nor seen them. I sent Geta to the sesquiplicarius and he said he had not received them. He called Alexander, the former curator, and he said he had received them and in turn had passed them on to Castoras. Seeing what you had sent, Artimas said grumbling: 'Woe on me, poor man, I am not able to supply them.' Greet my brother Sabinus and everyone. I pray for your health."

It can be concluded from the previous ostraca that Grata was preoccupied with identifying the person who received a shipment to Mons Claudianus from the Nile Valley. This shipment consists of 140 waterskins. It confirms at the end of the letter that the shipment was received by Alexander, the former Curator of the castle of Mons Claudianus. Here are two significant points:

A: The Curator's tasks at Mons Claudianus and indication of his competence to receive the shipment of waterskins.

B: The meaning of the term "waterskin".

Concerning the tasks of Curator in the quarries of Claudianus, a collection of ostracas from Mons Claudianus - dated back to the second century AD - shows that the site included a military castle ${ }^{35}$ headed by a military commander known as "Curator" 36 whose tasks included supervising the water and its supplies ${ }^{37}$. As for the term $\left.\alpha\right) \sigma \kappa o \varphi$, it means "waterskin or receptacle". It seems that Mons Claudianus managed to get these waterskins from the near 
provinces locating at a distance of three-days from the Nile Valley, namely Apollonopolis Magna (now Edfu), Koptos (now Qift), and the Tentoris (now Dendera). These provinces were well-known to meet the needs of both workers in the Eastern desert or travelers. It seems clear that they were raising many goats because waterskins were made only of goat $\operatorname{skin}^{38}$. Hence, it can be concluded that the waterskins were the appropriate means to carry water to the quarries of Claudianus or the Eastern desert of Egypt in general ${ }^{39}$. As long as the Curator was in charge of water supply, he must have been responsible for receiving the waterskins coming from the Nile valley for distribution to the water carriers at Mons Claudianus. In addition, this indicates that water carriers work under the supervision of the Curator of the military castle whether they were in Mons Claudianus or spread along the roads linking the quarries to the Nile valley. Due to the importance of waterskins in carrying water, it was necessary to take several measures to maintain and preserve them. An ostraca dating back to $107 \mathrm{AD}$, it can be found that Domitius - Curator of the castle of Claudianus quarries- tells Successus ${ }^{40}$ :

"Domitius curator to Successus, greetings. You gave me oil when yesterday I went down with the working decania and the bucket which I (now) send you (back),10 in order that you see what I used during the whole day. When he came down today to carry out just one trip of water carrying, he used twice as much. If you do not believe me, that he alone uses this, 11 send one of your men to sit here for a single day so that you may learn. Farewell."

Another ostraca dated back to $107 \mathrm{AD}$ is a letter from Leontas to Successus. It stated the following ${ }^{41}$ :

"Leontas to Successus, greetings. Please exchange the 4 water-skins and send me two baskets so that the water-skins do not suffer. Farewell."

The above two ostracas mentioned that preserving waterskins in the quarries of Claudianus required two basic things. First, there was a need to provide oil for painting them to maintain their elasticity and prevent cracking. Second: it was important to place waterskins in baskets avoid exposure to sun rays.

Undoubtedly, the water-carriers' method of using waterskins depended on the distance between the water supply and the destination. For example, when the water supply and the destination are close, water carriers rely only on themselves to carry and transport it, otherwise, animals are used. This is evident in an ostraca found in the quarries of Claudianus dating back to the second century $\mathrm{BC}$, which is an official letter sent to the Curator of Raima Castle. The letter says the following ${ }^{42}$ :

"Greeting to Sir Apolinaris the Curator of Raima castle. I would like you to inform that ....., I have sent the camels of the state to Akantha to get the water in order that we may not to be hurt. I sent the camels of the state and the civilians as well".

The previous letter shows that camels were used to transport water to long distances in the Eastern desert ${ }^{43}$. They were clearly divided into two types. The first was the camels of the state and was required by the Roman administration in the Nile valley to aid in the activities of the quarries for a specific period. The second type is the civil camels that apparently belonged to individuals who were investing them in quarrying ${ }^{44}$.

The previous letter also identifies a freshwater well in the Eastern desert, at Akantha area lying on the road leading to the Claudianus quarry ${ }^{45}$. It is worth mentioning that Akantha was not the only area with a freshwater well as there was another in an area of Raima that also located on the road leading to the Claudianus quarries ${ }^{46}$. There is no doubt that water carriers used to go to these wells to get fresh water and transport it to the quarries of Claudianus. 
This raises a question: about what follows in the quarries of Claudianus after bringing fresh water. To answer this question, the following can be cited ${ }^{47}$ :

"The second (of the month) Epip. The carriers clean the reservoirs and the backyard of the castle".

"The second (of the month) Epip. The carriers carry water to the reservoir"48.

Thus, it turns out that water carriers of the Claudianus quarries were carrying out various tasks from getting fresh water and carrying it on the backs of camels to the quarries to fill the reservoirs after cleaning them. In addition, they provide it in waterskins to the workers on the site either for drinking or for use in mining. There is a group of ostracas talking about distributing the rations of drinking water to workers in Claudianus quarries, it explained that the per capita share ranged between 2 and 3 liters per day ${ }^{49}$. Van der Veen said in his study of Claudianus quarries that the number of settlers was about 290 capita $^{50}$, this means that water carriers had to commensurate with these settlers, with the requirements of mining beside satisfying the needs of animals used to transport quarry products to the Nile valley.

\section{The archaeological evidence of water-carrier}

There are examples of figurines representing the profession of water-carrier. We will deal with Examples from the Egyptian Museum in Cairo and in the Graeco-Roman Museum in Alexandria.

\section{1- Terracotta figurine of water-carrier in the Egyptian Museum in Cairo (PI. 1, a, b} and c) No. 26752

Height: $8 \mathrm{~cm}$

Provenance: Naukratis

Roman Period

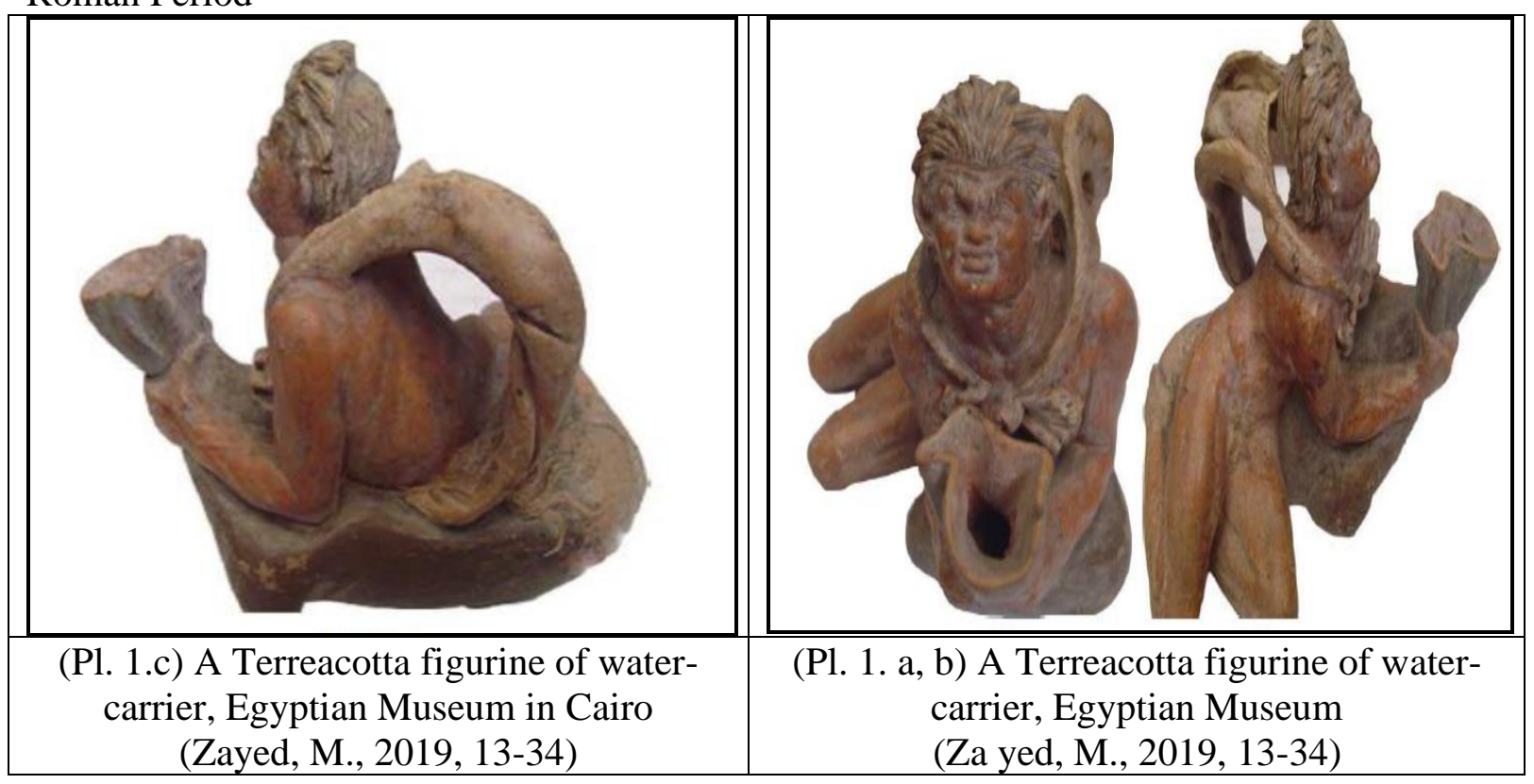

\section{Description:}

The terracotta figurine depicts a young man sitting in an irregular posture, holding a water skin (pl.1a). He is leaning to the ground on his knees, trunk and elbows bending over the water skin, is stretching his head forward up; and his legs backwards to rely on the water skin that he is leaning on, the base of the figurine itself (pl. 1.b). Meanwhile, he is holding the water skin and that represents and projecting its ring mouth, more likely to a fountain or a water source fall with a full concentrating looking face features, trying to fill it with water. ${ }^{51}$ 
The water carrier is shown naked except from a lion skinned band tied around his neck. The lion skin is recognized by the lion's paws tied around his neck and hanging down his back. $\mathrm{He}$ is leaning on a water band. There are some scattered hairs on the waterskin at the end of the band, (pl. 1.c), indicating that the band is made of a goat's skin. The suggestion that the water skin is made of a goat's skin is affirmed by two indications. First, the water skin takes a streamlined wavy shape as appears under the water carrier. Second, the mouth of the water skin is also wavy-shaped which is signified by his grip on it. The band and the lion skin together form a semi-circular shape designed perhaps to make the figurine easy to grasp through this cavity.

The water carrier is shown here with a plump face and furrowed forehead, the eyebrows are thick and linked together. The eyes incised carefully with circular upper and lower lids, and round irises and pupils. The nose is small. The mouth is slightly open, with fleshy parted lips and a pointed chin.

As for the hair style, it is treated entirely in the round, styled in protruding thick hair locks in three rows, it is notable that the locks get longer and looser as they reach the back of the neck, which is fully covered by hair, the neck is raised to look up straightly. The hair is hanging back loosely covering the whole back of the neck. It is noteworthy that thickness of the hair shortens the forehead on which some wrinkles are portrayed to represent the water carrier's seriousness and strict look.

The figurine is made from Nile silt which gives it the dark brown or reddish-brown color upon burning ${ }^{52}$. This type of silt is abundant in all areas of Delta and the Nile valley ${ }^{53}$. When comparing the color of its fired Nile silt to that of the terracotta collection preserved in the British museum whose source is Naucratis, we will find that the latter is dark brown. Nevertheless, many of them are glazed while the others are not ${ }^{54}$. Moreover, there are many similar terracotta pieces made from the same raw material preserved in the Greek and Roman museum in Alexandria, ${ }^{55}$

Concerning the technique, the figurine was undoubtedly hand-made, representing a unique and a rare condition. All the parts of the figurine are skillfully shaped. In fact, the artist excellently shaped the figurine and paid much attention to all the physiognomic details of the water-carrier body and managed to manifest seriousness on his face. Moreover, the technique known as "Sfomato" clearly appears in the plump, clear bones of face ${ }^{56}$. The artist was also skillful and professionally realistic in shaping the muscles of the body; however, the most expressive part of the figurine is the head area, the facial features, shape of hair, fleshy neck, and the flexibility of body. In fact, the execution of this distinguished posture was perfectly streamlined. This is in addition to the wavy effect added to the water skin. All these artistic features are in line with the style and artistic features of Praxiteles ${ }^{57}$, whose style influenced the Alexandrian school of art during the Greek and Roman times ${ }^{58}$.

This piece can be traced to the $2^{\text {nd }}$ century $A D$, especially the Antonine period due to the sharp concentrating look of the face, ${ }^{59}$ the incised circular eyelids ${ }^{60}$ as well as the heavy wavy locks of hair ${ }^{61}$.

By studying this figurine, we can conclude that the city of Naucratis ${ }^{62}-$ in which was found this piece, was a city of great importance at all times. This city started as a settlement in the Western Delta many centuries before Alexander the Great's invasion of Egypt, it continued to witness an economic prosperity until the Roman era. Thus, there is no doubt that discovering such a good quality and skillfully-made piece of art belonging to the second century AD indicates that the city was witnessing a renaissance at both the economic and cultural levels. Moreover, this indicates that it was undoubtedly inhabited during that period as deduced from 
the existence of a water-carrier who used to rove around the city from one end to the other to practice his profession.

It is also noteworthy that depicting the water carrier as naked showing a perfect body indicates the dominant Greek feature of sculpture. This indicates that Greeks represented the majority of the population of the city during the Roman era. This hypothesis is attested by literature on the subject and Greek papyri discovered in Egypt, which in total attest that Naucratis became a free Greek city. After the king Psamtik, I had devoted this city to all the Greek civilians residing in Egypt, the city of Naukratis became one of the three cities where the Greeks managed to reside during the Ptolemaic period with Alexandrians and Ptolemais and had special privileges and form the upper class ${ }^{63}$. During the Roman era the Romans considered the Hellenistic citizens of the three cities as privileged and preserved their previous advantages. In addition, during the Roman era, marriage was prohibited between the citizens of these cities and the nationalists in order to preserve the purity of their genre $^{64}$.

\section{2- Figurine of water-carrier in the Graeco-Roman Museum of Alexandria}

GRM. 23924, Room 16.

Height: $41 \mathrm{~cm}$

Provenance: Lower Egypt

Late Hellenistic Period

\section{Description}

This figurine is made out of white marble, this $41-\mathrm{cm}$-high figurine is purchased from Lower Egypt. The head of this figurine is missed. It represents the water carrier, which dates to the late Hellenistic Period ${ }^{65}$. The water carrier wears a transparent chiton leaving a good part of his chest uncovered. He carries a waterskin on his back tying it around his chest and shoulders with a double rope to tighten it up, thus referring to the heavy weight of the water skin. ${ }^{66}$ (pl. 2)

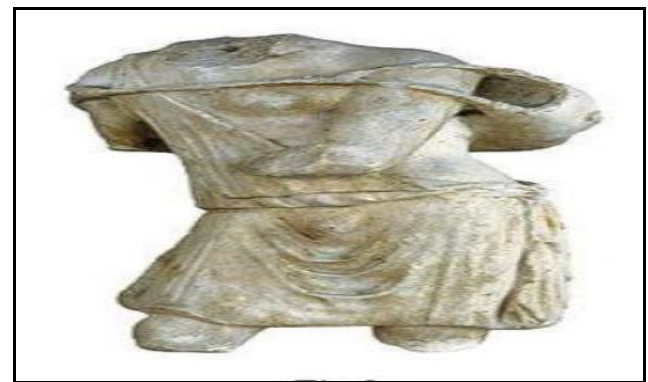

(Pl. 2) A Figurine of water carrier in the Graeco-Roman museum in Alexandria (Hassan, F. A., 2002)

A comparative study of the two models indicates the perfection of all the details of the parts of the statues and the skill in depicting it at a particular moment. In the model of the GrecoRoman museum, the artist depicts the water carrier while performing his work, he carries his water skin on his back, walks and it slightly bends forward. He is suffering from the heavy weight of the water skin. In the model of the Egyptian museum the artist represents the water carrier at the moment of relaxation, perhaps after his work. Despite this diversity, the figuration of both models demonstrates an unprecedented stage of artistic prosperity.

\section{Results}

The profession of the water carrier was attested in the papyri dating back to the GraecoRoman period. This profession was known in the papyri as $v(\delta \rho \circ \phi о \rho \circ \varphi$. According to the documents of the Ptolemaic period, water carriers played an important role in providing fresh water to the people for household use in general, for domestic use and for construction. 
Another collection of papyri mentioned daily accounts of the costs of buying fresh water from water carriers which was about half an obol (less than 1/10 a drachma) at a time during the third century BC.

As for the evidence of the profession of water carrier during the Roman period, there are two groups, the first indicated the important role of the water carrier in supplying water to villages and cities for use in various purposes. The second deals with the role of water carrier in transporting water to the quarries especially of Mons Claudianos and military installations scattered in the Eastern desert of Egypt.

Due to the importance of this profession It seems that during the period between the fourth and fifth centuries AD, Egypt witnessed an administration specialized in issuing official certificates relating to the water carrier profession and the conditions necessary for practicing this profession.

As for the means used to carry water, they used water skins made of goat skin. Several measures were taken to maintain and preserve them.

When we compare between the documents of the Ptolemaic and Roman period, we find that during the Ptolemaic period the work was limited to supplying water to villages and cities for use in various purposes. During the Roman period the work included supplying water to the quarries in the Eastern desert. In the late Roman period the work was organized and required official certificates to practice this profession.

The profession of water-carrier was represented by figurines of terracotta. The terracotta examples were used to indicate that artists during the Graeco-Roman period were keen to reflect the activities of all the classes of the Egyptian society, especially lower ones. This profession as represented by these figurines required a physical strength.

The study also reveals that the profession of water carriers was widespread in small towns and gained reputation outside the capital city as both models were discovered in Delta.

Furthermore, the settlement of Naucratis boomed during the Roman era and was distinctive as far as culture and art are concerned. However, some other figurines were shaped manually, in which case special attention was paid to all the details of the figurine.

\section{Conclusion:}

The role played by the profession of water carriers is evident in the considered papyri and the ostracas in addition to terracotta figurines. People in provinces and villages scattered throughout Egypt relied on water carriers to buy water, either for household use or for irrigation and construction. They had a prominent role in providing water to the settlers of Claudianus quarries in the Eastern desert of Egypt. They used water skins for carrying water, and depended on donkeys and camels for transporting to long distances especially in the Eastern desert. It is clear that they played an important role in creating new administrative and economic ideas during the Ptolemaic and Roman rule in Egypt. The artists during the Graeco-Roman period were keen to reflect the activities of all the classes of the Egyptian society, especially lower classes, so this profession was represented by figurines of terracotta. 


\section{References}

\section{1- Papyri}

- P.Cair.Zen. = Zenon Papyri, Catalogue général des antiquités égyptiennes du Musée du Caire, vol. IV, ed. C.C. Edgar. Cairo, 1931.

- P. Enteux. = ENTEYछEIS: Requêtes et plaintes adressées au Roi d'Égypte au IIIe siècle avant J.-C., ed. O. Guéraud. Cairo 1931-32

- P. Lond. = Greek Papyri in the British Museum. London. Vol VII, the Zenon Archive, ed. T.C. Skeat. London. 1974

- P. Mil. Vogl. =VII, La contabilità di un'azienda agricola nel II sec. d.C., ed. D. Foraboschi. Milan 1981. Nos. 301-308

- P.Petr. = The Flinders Petrie Papyri. Dublin. Vol. III, III, ed. J.P. Mahaffy and J.G. Smyly. 1905

- P. Princ. = Papyri in the Princeton University Collections. Vol. II, ed. E.H. Kase, Jr. Princeton 1936.

- P.Ryl. = Catalogue of the Greek and Latin Papyri in the John Rylands Library, Manchester. Manchester. Vol. III, Theological and Literary Texts, ed. C.H. Roberts. 1938.

- PSI. = Papiri greci e latini. (Publicazioni della Società Italiana per la ricerca dei papiri greci e latini in Egitto). Vol. V, Ed., G. Vitelli and M. Norsa, Florence.

- SB. = Sammelbuch griechischer Urkunden aus Aegypten . Begun by F. Preisigke in 1915, continued by F. Bilabel, E. Kiessling, and H.-A. Rupprecht), Vol. I, Strassburg and Berlin 1913-1915; V, Heidelberg and Wiesbaden 1934-1955; VI, Wiesbaden 1958-1963.

- UPZ. = Urkunden der Ptolemäerzeit (ältere Funde), ed. U. Wilcken. Vol. I, Papyri aus Unterägypten. Berlin—Leipzig 1927

\section{- Ostraca}

- O.Claud. = Mons Claudianus. Ostraca graeca et latina. Vol. I-II, ed. J. Bingen, Cairo, 1992-1997; Vol. IV, ed. A. Bülow-Jacobsen. Cairo 2009

- O.Krok. = Ostraca de Krokodilô. Vol. I, La correspondance militaire et sa circulation, ed. H. Cuvigny. Cairo 2005.

\section{- Foreign references}

- Adams, C., 2007, Land Transport in Roman Egypt A Study of Economics and Administration in a Roman Province, Oxford University press.

- Clarysse, W., Vandorpe, W., 1995, Zenon, Un Homme d'affairs grec a l'ombre des pyramids, Ancorae 14, Leuven.

- Barans, J., 1978, Egyptians and Greeks, P.Brux. 14.

- Bereccia. E., 1930, Terre Cotte Figurate Greche e Greco-Egizie del Museo di Alessandria, in Monnments d'Egypte Greco-Romaine. II, Bergamo.

- Boardman, J., 1984, Greek Sculpture. The Calassical Period, London.

- Daniel, R.W., 1994, "Neither do they put new wine in old skins', Zeitschrift fur Papyrologie und Epigraphik, 101.

- Dunand, 1990, Catalogue des Terres cuites Greco Romain d'Egypte, Paris.

- Hassan, Fekri A. (ed.) 2002. Alexandria: Graeco-Roman Museum, a thematic guide, the Supreme Council of Antiquities. 
- Higgins, R., 1969, Terracottas of Greek and Roman Antiquities in The British Museum. Vol. 1. London.

- Hirt, A.M., 2010, Imperial Mines and Quarries in the Roman World, Organizations Aspects 27 BC 235 AD, United States, Oxford University Press.

- Kleiner, D., 1992, Roman Sculpture.

- Orrieux, 1983, Les papyrus de Zenon, L'horizon d'un grec en Égypte au IIIe siècle avant J.-C, Paris: Macula

- Pedley, J., 2002, Greek Art and Archaeology, $3^{\text {rd }}$ Ed., London.

- Pollitt, J., 1986, Art in Hellinistic Age, Cambridge.

- Prinz, H., 1908, Funde aus Naukratis, Beitrage zur Archaologie und Wirtschajtsgeschichte des VII. Und VI. chr. Leipzig.

- Reden, S.V., 2007, Money in Ptolemaic Egypt: from the Macedonian Conquest to the End of the Third Century B.C., Cambridge University Press, Cambridge.

- Rostovtzeff, 1922, A Large Estate in Egypt in the Third Century BC, A Study in Economic History. Madison.

- Rowlandson, J.,1998, Women and Society in Greek and Roman Egypt: A Sourcebook, Cambridge: Cambridge University Press.

- Russell, D., 2001, The Art of prose: The early Empire in The Roman World, Ed. John Boardman, Oxford Uni. Press.

- Shaheen, Alaa el-din M., 2007, "'Water Carrier' or the Like in the Ancient Egyptian Sources and Its Resemblance to Dilum Glyptic Art," in The Archaeology and Art of Ancient Egypt. Essays in Honor of David B. O'Connor, Volume II.

- Shier, L., 1906, Terracotta Lamps from Karanis, Michigan.

- Sidebotham, S.E., 2011, Brenike and the Ancient Maritime Spice Route, University of California Press.

- Stafford, E., 2004, Ancient Greece, Life, Myth and Art, London

- Veen, V. D.M., 1998, "A life of Luxury in the Desert? The Food and Fodder Supply to Mons Claudianus", Journal of Roman Archaeology, XI.

- Verreth, H., 2008, A survey of Toponyms in Egypt in the Graeco-Roman Period, Koln/Leuven.

- Woodford, S., 1982, The Art of Greece and Rome, Cambridge University Press.

- Zayed, M., 2019, Publication and Study of a Rare Terracotta Piece from Naucratis Preserved in the Egyptian Museum in Cairo, International Journal of History and Cultural Studies, Vol 5, Issue 2.

- Zitterkopf, R.E., Sidebotham, E., 1989, "stations and towers on the Quseir-nile Road", JEA 75.

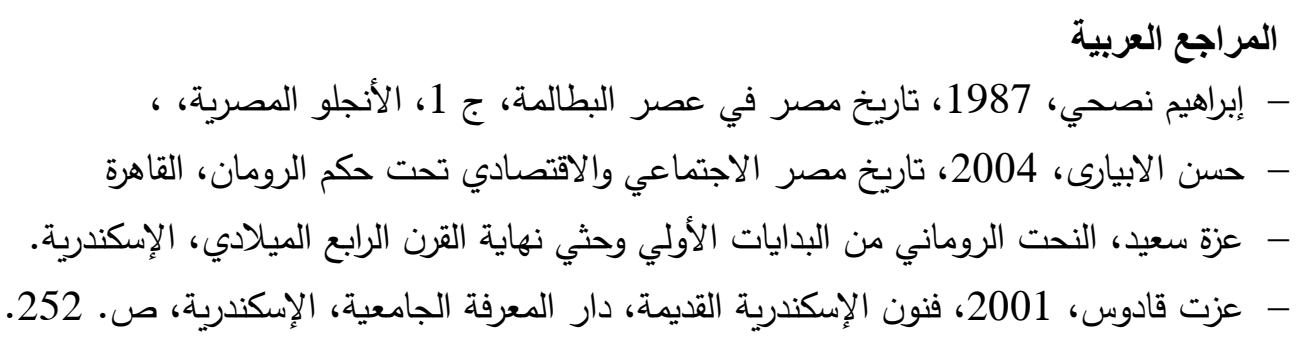




\section{End Not:}

${ }^{1}$ Such as the tomb of Mereruka in Saqqara, tomb of Ni-ankh-khnum and Khnum-hotep at Saqqara and Rekhmire's Theban tomb,

${ }^{2}$ Shaheen, Alaa el-din M., 2007, "'Water Carrier' or the Like in the Ancient Egyptian Sources and Its Resemblance to Dilum Glyptic Art," in The Archaeology and Art of Ancient Egypt. Essays in Honor of David B. O'Connor, Volume II, 369-380.

${ }^{3}$ P.Cair.Zen. IV. 59702, Account of Daily Expenses, Philadelphia (Arsinoites), 275-226 BC; P. Lond. VII 2140, An Account, Philadelphia, 275-225 BC; SB. V. 7642, a Letter from Maron to Zenon, Philadelphia, 257 BC; P. Princ. II. 18, grain accounts, Provenance unknown, 225-201 BC; P. Enteux. 78, violence against water carrier, Magdola, Krokodilopolis (Arsinoites), 26-27 Febr. 221 BC; PSI. V 528, a Letter from Kleon to his father Zenon, Philadelphia, 3rd Century BC; P.Petr. III 137, a Private Accounts, Gurob (Arsinoites), 3rd Century BC.

${ }^{4}$ Philadelphia which means in ancient Greek "City of Brotherly Love" was a city dedicated to Arsinoe sister of Ptolemy II Philadelphus. It was located along the eastern edge of Fayum. Now it is called Gharabet el-Gerza. Many of the papyri from Philadelphia come from the Zenon Archive, the estate manager of Apollonios.

${ }^{5}$ Maron was an official in the Large Estate of Apollonius at Philadelphia. The Latter was the finance minister of Ptolemy II. Maron also was the sub-manager of the estate under Panakestor the manager of the Estate. Rostovtzeff, 1922, A Large Estate in Egypt in the Third Century BC, A Study in Economic History. Madison.

${ }^{6}$ P.Ryl. 4 559; SB. V. 7642.

7 PSI V, 528; translated in Rowlandson, 1998, Women and Society, 76; Orrieux, 1983, Les papyrus de Zenon, 134-135; Clarysse - Vandorpe, 1995, Zenon, 61-62

${ }^{8}$ It is possible that Zenon adopted Kleon and spent on him and his widowed mother. Clarysse, W., Vandorpe, W., 1995, Zenon, Un Homme d'affairs grec a l'ombre des pyramids, Ancorae 14, Leuven, pp. 61-62; Rowlandson, J., 1998, Women and Society in Greek and Roman Egypt: A Sourcebook, Cambridge: Cambridge University Press, p.96; Reden, S.V., 2007, Money in Ptolemaic Egypt: from the Macedonian Conquest to the End of the Third Century B.C., Cambridge University Press, Cambridge, p. 236 no. 32.

9 Hermes's feast was the special Hermaea which was celebrated with sacrifices to the god and with athletics and gymnastics, possibly having been established in the 6th century BC, but no documentation on the festival before the 4th century BC survives while the Mousai (Muses) were nine goddesses of literature, science, and the arts like music, poetry, dance and song.

${ }^{10}$ Krokodilopolis was an ancient Egyptian city located in Fayum Oasis, west of the Nile. Its modern name is Fayum. It has always been the capital city of the Fayum region. The town was founded in early dynastic period and flourished during the Middle Kingdom as Shedet - the oldest and most important centre of a crocodile god Sobek in Egypt. Known to the Greeks as Krokodilopolis, from the reign of Ptolemy II Philadelphos (285-246 BC) and his sister-spouse Arsinoe II it became a Greek city and received a new name Arsinoe

${ }^{11}$ P.Enteux. 78, 1-6; this letter was one of the petitions and notifications to Ptolemaic officials concerning crimes.

12 P.Enteux. 78, 1.

${ }^{13}$ P.Petr. III. 137, L.7.

${ }^{14}$ P.Cair.Zen. IV. 59702, L. 24.

${ }^{15}$ P.Lond. VII. 2140, LL. 2-3.

${ }^{16}$ P.Princ. II. 18, L. 7.

${ }^{17}$ Obol was a form of ancient Greek currency and weight. It equals one-sixth of a drachma. The smallest coin denomination.

${ }^{18}$ Drachma $=6$ obols: if in silver, it corresponds to the wage of a soldier in the $3^{\text {rd }}$ century BC.

${ }^{19}$ SB. VI. 9494, List of Expenses for Agricultural Works, Tebtunis 162-167 AD; P.Mil.Vogl. VII. 304, An Account for workers and building a wine press, Tebtunis, 16 Aug. 166 AD; UPZ. I. 120, Judicial Report, Memphis, $2^{\text {nd }}$ Century AD; $S B$. VI. 9095, daily record, provenance unknown, $3^{\text {rd }}$ century AD; 
SPP. XXII. 75, rations, Soknopaiu Nesos (Arsinoites), $3^{\text {rd }}$ Centurt AD; P.Ryl. IV. 630-637, travel accounts, Hermopolis Magna (Modern el-Ashmunein on the west bank of the Nile in Minia Governorate), 317-323 AD; SB. I. 1976, water carrier, Oxyrhnchos, 27 May. 401-500 AD.

${ }^{20}$ O.Krok. I. 69, a letter from Papinnius Rufus to Marcus Titusenus, Krokodilopolis, 98-117 AD; O.Krok. I. 78, a letter to the Curator, 98-117 AD; O.Claud. IV. 784, an account of Askoi to quarries, Mons Claudianus, 98-117 AD; O.Claud. IV. 785, an order for delivery of water skins, 98-117 AD; O.Claud. IV. 824, a letter from Leontas to Epaphroditus, 98-117 AD; O.Claud. IV. 867, a letter, 98117 AD; O.Claud. I. 126, a letter from Grata to Successus, 107 AD; O.Claud. I. 127, a Letter from Art imas to Successus and Sabinus, 107 AD; O.Claud. I. 128-129, a letter from Leontas to Successus, 107 AD; O.Claud. I. 134, a letter from Domitus to Successus, 107 AD; O.Claud. IV. 819, an official letter of requisition, $110 \mathrm{AD}$; O.Claud. IV. 723-726, lost of personnel 136-137 AD; O.Claud. IV. 840, a account of various deliveries, 136-137 AD; O.Claud. IV. 757, a list of completed works, 138161 AD; O.Claud. . IV. 758, 761, a list of completed works, 138-161 AD; O.Claud. IV. 728, 729, distribution of men for other jobs, 140-145 AD; SB. XVIII. 13336, letter, I-II AD; O.Claud. II. 362, Apolinaris, curator of Raima, Mons Claudianus, II AD.

${ }^{21} S B$ VI. 9494, LL. 21-22.

22 P.Mil.Vogl. VII. 304.

${ }^{23}$ A standard of weight as well as a coin. There were six obols to a drachma, sixty drachmas to a mina, and sixty minas to a talent. The weight and value of a drachma varied widely in the Hellenistic period.

${ }^{24}$ UPZ. I. $120=$ P.Paris. 34.

${ }^{25} S B$ VI. 9095, L. 12; SPP. XXII 75, L. 9.

${ }^{26}$ The village was an ancient settlement in Faiyum Oasis, situated a few kilometers north of Lake Qarun. This vallage is known today as Dimeh El Sebaa. It was an important religious center where was a temple for god Soknopaios. According to papyrological evidence Soknopaiou Nesos was established in the $3^{\text {rd }}$ century BC, during a project of land reclamation in Faiyum carried out by the first Ptolemies, and was abandoned in mid $3^{\text {rd }}$ century CE.

${ }^{27}$ P.Ryl. IV. 630-637, L. 331.

${ }^{28}$ SB. I. 1976.

${ }^{29}$ Mons Claudianus is situated in a remote part of Egypt's Eastern Desert, about $500 \mathrm{~km}$ south of Cairo and $120 \mathrm{~km}$ east of the Nile, at an altitude of about 700 meters in the heart of the Red Sea Mountains. The site itself is a quarry settlement renowned for its granodiorite used during the Roman rule in Egypt for imperial construction in Rome. It comprises a fort and its outbuildings (hydreuma, stables, baths).

The archeological remains indicate that during the late first and second centuries AD, the site's most $\mathrm{i}$ ntense occupation happened. Between 1987 and 1993, the Institut Français d'Archéologie Orientale in Cairo conducted a work by a permission of the Egyptian Antiquities Organisation. The work resulted in the discovery of 9200 ostracas from the period of the Roman rule in Egypt. Jean Bingen, Adam Bülow-Jacobsen, E.H. Walter, E.A. Cockle, and Van Rengen published some of these ostracas in a book entitled Mons Claudianus, Ostraca graeca et latina I (O. Claud. 1 à 190), Institut Français d'Archéo logie Orientale, Le Caire, 1992.

${ }^{30}$ Veen, V. D.M., 1998, "A life of Luxury in the Desert? The Food and Fodder Supply to Mons Claudianus", Journal of Roman Archaeology, XI, PP. 101-16; Hirt, A.M., 2010, Imperial Mines and Quarries in the Roman World, Organizations Aspects 27 BC 235 AD, United States, Oxford University Press, esp. chap. 3-4.; Sidebotham, S.E., 2011, Brenike and the Ancient Maritime Spice Route, University of California Press, pp. 73; 81; 89; 91; 99-100; 117-122.

${ }^{31}$ O.Claud. IV. 723, L. 16; O.Claud. IV. 724, L. 2; O.Claud. IV. 726, L. 1; O.Claud. IV. 761, L. 8; O.Claud. IV. 840, L. 8; O.Claud. IV. 728, L. 10; O.Claud. IV. 729, L. 8. 
${ }^{32}$ O.Claud. IV. 725, LL. 1-32.

${ }^{33}$ O.Claud. I. 126, LL. 1-13

${ }^{34}$ It is evident from a group of ostracas (O.Claud I. 124-163) dating back to the second century AD that Successus was responsible for providing most of the work supplies to the quarries of Mons Claudianus such as firewood, baskets, ropes, cloaks, chisels, handles and axes, as well as leather water skins O.Claud. I. 126, LL. 1-13

${ }^{35}$ The fort of Krocodilo (Kроко $\left.\delta \lambda \hat{\omega}\right)$ modern El-Muwayh is located in the Eastern desert to the west of Wadi Hammamat, along the road between Koptos (Qift) and Myos Hormos (Quseir el-Qadim). (see: Cuvigny ed.), La route de Myos Hormos, 2003, p. 54; p. 278-280; Cuvigny, O. Krok. 1, 2005; Cuvigny, Le désert oriental d'Égypte, 2018, § 105-173

${ }^{36}$ O.Claud. I. 78; I. 48-49; 82; I. 126; I. 134; I. 148-149; II. 222; II. 224-226; II. 228; II. 232-234; II. 357-382; II. 384-385; II. 387, $2^{\text {nd }}$ Century AD.

37 The quarries of Mons Claudianus and the road net-work linking it to the Nile valley included several military forts. Each fort was administraered by a Curator. One of his main tasks is to supply water to the quarries. An ostraca was found in the fort of Krocodilo it dates back from 98 AD to 117 AD. Thisostraca is an official letter sent by Papinius Rufus to Marcus Titusenus, Curator of Krocodilo. He asks the Curator to do his best on the water supply issue: O.Krok. I. 69, LL. 4-12.

${ }^{38}$ Zitterkopf, R.E., Sidebotham, E., 1989, "stations and towers on the Quseir-nile Road", JEA 75, pp. 165-170; Daniel, R.W., 1994, "Neither do they put new wine in old skins', Zeitschrift fur Papyrologie und Epigraphik, 101, p. 62.

${ }^{39}$ There are a number of Ostracas which reflect the large demand for water skins and the importance of supplying the quarries with them, O.Claud. IV. 784, L. 1; O.Claud. IV. 785, LL. 1-3; O.Krok. I. 78, L. 6; O.Claud. IV. 824, L. 4; O.Claud. IV. 867, L. 3; O.Claud. I. 127, LL. 10-11; O.Claud. IV. 819, LL. 4-6.

${ }^{40}$ O.Claud. I. 134.

${ }^{41}$ O.Claud. I. 128, LL. 1-6.

${ }^{42}$ O.Claud. II. 362, LL. 1-10.

${ }^{43}$ It was necessary to select good camels to carry water skins, in a letter dated back to the $2^{\text {nd }}$ Century $\mathrm{AD}$, the messenger asks from the receiver of the letter to supply him with perfect camels for carrying water. SB. XVIII. 13336, LL. 7-10.

${ }^{44}$ Adams, C., 2007, Land Transport in Roman Egypt A Study of Economics and Administration in a Roman Province, Oxford University press, p.135.

${ }^{45}$ Verreth, H., 2008, A survey of Toponyms in Egypt in the Graeco-Roman Period, Koln/Leuven, p. 31

${ }^{46}$ Verreth, 2008, p. 496.

${ }^{47}$ O.Claud. IV. 758, LL. 1-5.

${ }^{48}$ O.Claud. IV. 757, LL. 1-3

${ }^{49}$ O.Claud. IV. 704; 770-771; 774-778; 780-783; List of distribution of water to quarries.

${ }^{50}$ Veen, 1998, p. 101.

${ }^{51}$ Zayed, M., 2019, Publication and Study of a Rare Terracotta Piece from Naucratis Preserved in the Egyptian Museum in Cairo, International Journal of History and Cultural Studies, Vol 5, Issue 2, PP 31-34.

${ }^{52}$ Prinz, H., 1908, Funde aus Naukratis, Beitrage zur Archaologie und Wirtschajtsgeschichte des VII. Und VI. chr. Leipzig, pp. 84-86; Shier, L., 1906, Terracotta Lamps from Karanis, Michigan.

$$
53 \text { عزت قادوس، 2001، فنون الإسكندرية القديمة، دار المعرفة الجامعية، الإسكندرية، ص. }
$$

${ }^{54}$ Higgins, R., 1969, Terracottas of Greek and Roman Antiquities in The British Museum. Vol. 1. London, pp. 404-407, no 1542-50.

${ }^{55} \mathrm{~A}$ large head negro figurine Bereccia. E., 1930, Terre Cotte Figurate Greche e Greco-Egizie del Museo di Alessandria, in Monnments d'Egypte Greco-Romaine. II, Bergamo, pp. 5-8; Dunand, 1990, Catalogue des terres cuites Greco romain d'Egypte, Paris. pp. 15-19.

${ }^{56}$ Pedley, J., 2002, Greek Art and Archaeology, $3^{\text {rd }}$ Ed., London, p. 308.

${ }^{57}$ Praxiteles, (flourished 370-330 BCE), greatest of the Attic sculptors of the 4th century BC and one of the most original of Greek artists. For the school of Praxiteles and its artistic features see: Bowder, 
D.,1982, Who was who in the Greek World, 776 - 30 BC, Cornell University Press, pp. 175-176; Boardman, J., 1985, Greek Sculpture, the Classical Period, London, pp. 206-207; 215-217; Fullerton, M., 2000, Greek Art, Cambridge Uni.Press ,p. 74 , fig . 54.

${ }^{58}$ Boardman, J., 1984, Greek Sculpture. The Calassical Period, London, pp. 69-71.; Pollitt, J., 1986, Art in Hellinistic Age, Cambridge, p. 161; Pedley, 2002, pp. 307-309; Stafford, E., 2004, Ancient Greece, Life, Myth and Art, London, p. 66.

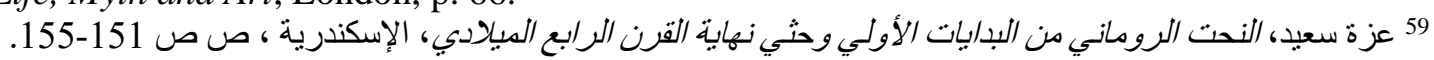
${ }^{60}$ Kleiner, D., 1992, Roman Sculpture, pp. 268-270.

${ }^{61}$ Woodford, S., 1982, The Art of Greece and Rome, Cambridge University Press, pp. 86-87; Russell, D., 2001, The Art of prose: The early Empire in The Roman World, Ed. John Boardman, Oxford Uni. Press, pp. 243-266.

${ }^{62}$ It is the modern village of Kom Gieif, city of Kom Hamada, Beheiara Governorate. It is located on the Canopic branch of the River Nile about $80 \mathrm{~km}$ southeast of Alexandria. It was settled firstly by Melitian Immigranes in the 7th century BC. It was the first and the only permanent Greek colony in Egypt. it was established during the $26^{\text {th }}$ dynasty in order to be a settlement for the employed eastern Greek and Carian mercenaries in the Egyptian army.

${ }^{63}$ Barans, J., 1978, Egyptians and Greeks, P.Brux. 14, p. 7.

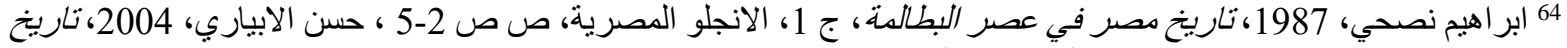

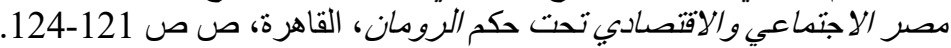

${ }^{65}$ Bonacasa, N., 1960. "Segnalazioni Alessandrine II. Sculture minori del Museo Greco Romano di Alessandria”, ArchClass. XII, p.170 ff.; Adriani, 1972, Lezioni sull'arte alessandrina. Napoli: Libreria scientifica editrice, p. 141, no. 3, tav. 25, 3;, 59; Haggag, M., 2019, 'Cosmopolitan Trends in the Arts of Ptolemaic Alexandria, Edições Afrontamento'; in: CITCEM - Centro de Investigação Transdisciplinar Cultura, Espaço e Memória; Centro de Estudos Clássicos e Humanísticos; Alexandria University; Imprensa da Universidade de Coimbra. 93, fig. 5a, b.

${ }^{66}$ Hassan, Fekri A. (ed.) 2002. Alexandria: Graeco-Roman Museum, a thematic guide, the Supreme

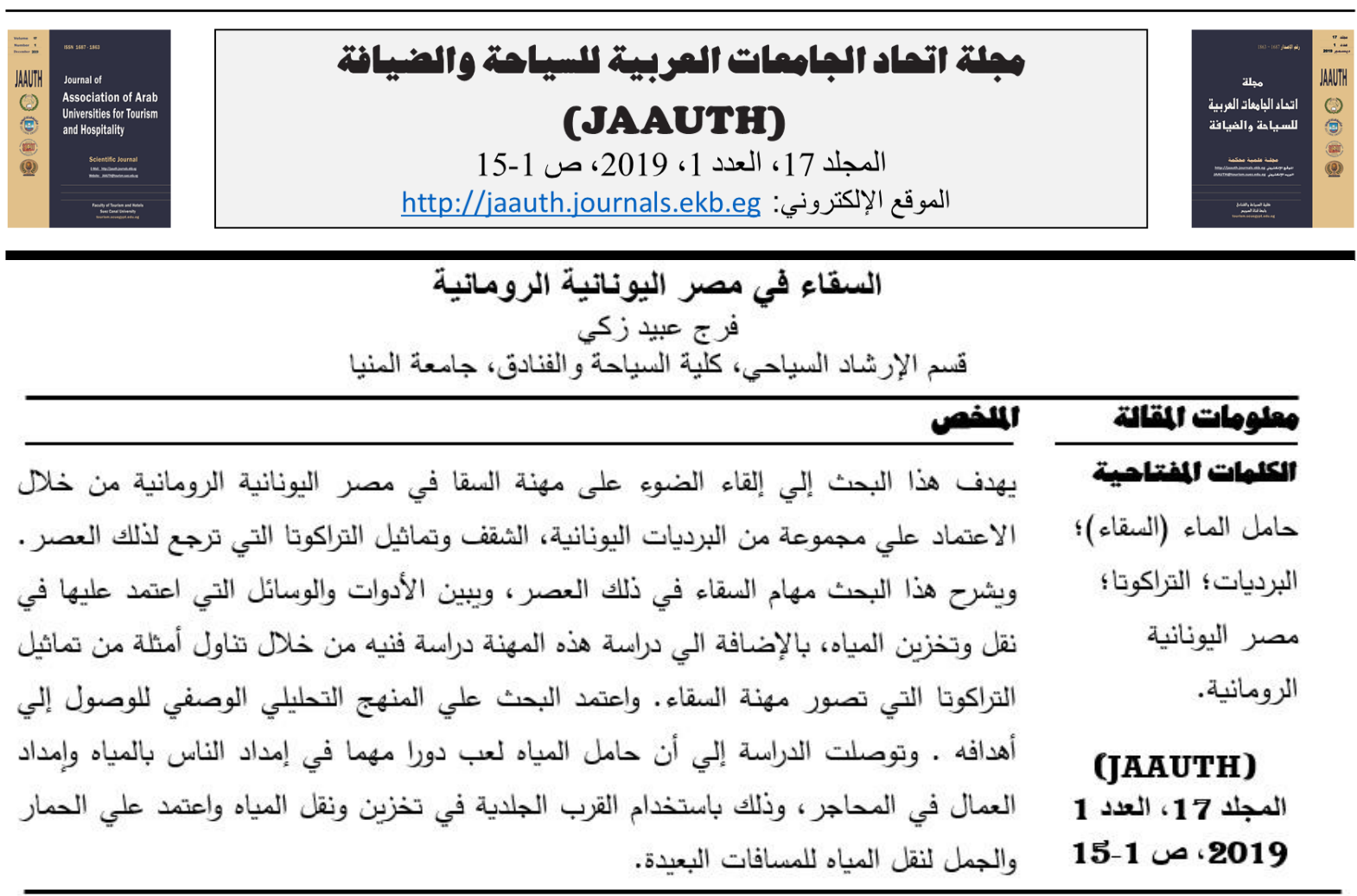

